\title{
Modification of Duval Triangle for Diagnostic Transformer Fault through a Procedure of Dissolved Gases Analysis
}

\author{
Sobhy S. Dessouky ${ }^{\text {A }}$, Ahmed E.Kalas ${ }^{\text {B }}$, R.A.Abd El-Aal ${ }^{\text {C }}$, Abdel Moneim M. Hassan ${ }^{\text {D }}$ \\ A, B,C Electrical Engineering Dept. Faculty of Engineering, Port-Said University. Port Said, Egypt \\ D Abo-Sultan Steam Power Plant, Ismailia. Egypt
}

\begin{abstract}
Dissolved gas-in-oil analysis (DGA) is a sensitive and dependable technique for the detection of incipient fault condition within oil-immersed transformers. When the mineral oil is subjected to high thermal or/and electrical stresses, it decomposes and, as a result, gases are generated.

This paper presents modification of Duval triangle DGA diagnostic graph to numerical method that is easy to use for diagnosing and a Matlab program. To study such as the following evaluation. This evaluation is carried out on DGA data obtained from three different groups of transformers each group are two identical transformers. A Matlab program was developed to automate the evaluation of Duval Triangle graph to numerical modification, Also the fault gases can be generated due to oil decomposing effected by transformer over excitation which increasing the transformer exciting current lead to rising the temperature inside transformer core beside the other causes.
\end{abstract}

Index Terms - Dissolved Gas Analysis (DGA), mineral oil, decomposition, degradation, and transformer condition.

\section{INTRODUCTION}

$\mathrm{D}$ issolved gas analysis (DGA) is a popular diagnostic technique that is used to detect incipient faults in oil-filled power transformers [1]. By using DGA data, transformer criticality can be identified with proposing the proper maintenance action [2].

Several methods were proposed to diagnose incipient faults based on DGA. These methods are key gas method, Rogers's ratio methods, Duval triangle method, Doernenburg Ratio method, Basic Gas Ratio, and artificial intelligence based methods.

The key gas method identifies the key gas for each type of fault and uses the percent of this gas to diagnose the fault as suggested by IEEE standard C57.104 [3]. The percent amount of gas is obtained in terms of the total combustible gases (TCG). The main disadvantage of this method is that the interpretation

Sobhy S. Dessouky, Electrical Engineering Dept. Faculty of Engineering, Port-Said University. Port Said, Egypt (e-mail: sobhyserry@yahoo.com). Ahmed E.Kalas, Electrical Engineering Dept. Faculty of Engineering, PortSaid University. Port Said, Egypt (e-mail: kalas_14@yahoo.com). by the individual gases is difficult in practice since each incipient fault produces traces of other gases in addition to the key gas of such fault. The ratio methods for fault diagnosis use certain ratios of dissolved gas concentrations according to combinations of codes [4, 5]. An incipient fault is detected when a code combination matches with the code pattern of the fault. The most widely used ratio methods are the Doernenburg Ratio Method, Rogers Ratio Method, and IEC standard. Six gas ratios have been used by different methods. The major drawback of ratio methods is the "no decision" problem associated with some cases that lie out of the specified codes.

In recent years, many researchers have studied the application of artificial intelligence based techniques for transformer fault diagnosis. These techniques include expert systems, fuzzy logic, artificial neural networks or mixed techniques $[6,7]$. However, these methods are too complicated to be implemented practically on a wide range.

This paper investigates the new aspects, accuracy and consistency of these methods in interpreting the transformer condition.

\section{DGA TO DIAGNOSE TRANSFORMER FAULTS}

When an incipient fault occurs, either thermal or/and electrical, a number of gases are generated and dissolved into the oil. These gases are mainly $\mathrm{H}_{2}, \mathrm{CH}_{4}, \mathrm{C}_{2} \mathrm{H}_{2}, \mathrm{C}_{2} \mathrm{H}_{4}$ and $\mathrm{C}_{2} \mathrm{H}_{6}$. In addition $\mathrm{CO}$ and $\mathrm{CO}_{2}$ will exist if cellulose degradation is involved, based on the type and amount of generated gases [1, 8-9].

\section{A. Duval Triangle (DGA) Diagnostic Graph Method}

M. Duval. Proposed another diagnostic method to overcome this limitation, well known as Duval triangle. This method is based on a triangle graphical representation to visualize the different cases for oil-insulated high-voltage equipment (mainly transformers), Fig. (I) provides a graphical method of identifying a fault. It uses a three-axis coordinate

R.A.Abd El-Aal, Electrical Engineering Dept. Faculty of Engineering, PortSaid University. Port Said, Egypt (e-mail: ramadanhv@yahoo.com).

Abdel Moneim M. Hassan, Abo-Sultan Steam Power Plant, Ismailia. Egypt (e-mail: abdelmoname333@yahoo.com). 
system, where concentrations of $\mathrm{CH}_{4}, \mathrm{C}_{2} \mathrm{H}_{4}$ and $\mathrm{C}_{2} \mathrm{H}_{2}$ are used as coordinates, and the likely fault falls within one of the fault regions of the triangle. The various regions within the Duval Triangle are given in Table (I) [10-13].

For example if $\mathrm{C}_{2} \mathrm{H}_{2}=0.07, \mathrm{CH}_{4}=0.2$ and $\mathrm{C}_{2} \mathrm{H}_{4}=0.73$. The fault diagnostic is T3 (Thermal fault $\mathrm{t}>700^{\circ} \mathrm{C}$ ), and if $\mathrm{C}_{2} \mathrm{H}_{2}=0.36, \mathrm{CH}_{4}=0.32$ and $\mathrm{C}_{2} \mathrm{H}_{4}=0.32$, the fault diagnostic is D2 (High-energy electrical discharge), as shown in fig (I).

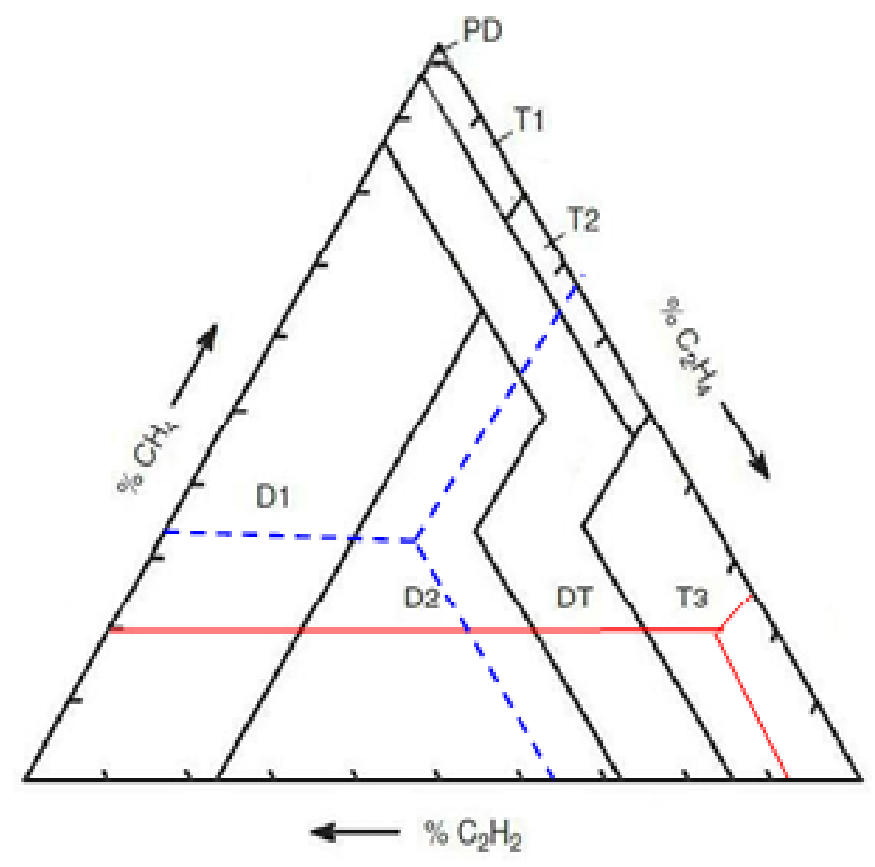

Fig. 1. Duval Triangle

\begin{tabular}{|r|c|}
\hline \multicolumn{2}{|c|}{ TABLE I. FAULT CODE } \\
\hline PD & Partial discharge \\
\hline T1 & Low-range thermal fault (below $\left.300^{\circ} \mathrm{C}\right)$ \\
\hline T2 & Medium-range thermal fault $\left(300-700{ }^{\circ} \mathrm{C}\right)$ \\
\hline \hline T3 & High-range thermal fault (above $\left.700^{\circ} \mathrm{C}\right)$ \\
\hline \hline D1 & Low-energy electrical discharge \\
\hline \hline D2 & High-energy electrical discharge \\
\hline \hline DT & Indeterminate - thermal fault or electrical discharge. \\
\hline
\end{tabular}

\section{A. Duval Triangle Graph to Numerical Method}

In this paper, we developed A Matlab program to automate the evaluation of Duval Triangle graph to numerical modification. Table (II) shows the Modification of Duval triangle DGA diagnostic graph to numerical method.

For example if $\mathrm{C}_{2} \mathrm{H}_{2}=0.1, \mathrm{CH}_{4}=0.3$ and $\mathrm{C}_{2} \mathrm{H}_{4}=0.6$. We can use table (II) easy to determine the fault Diagnostic (Thermal fault $\mathrm{t}>700^{\circ} \mathrm{C}$ ), and if $\mathrm{C}_{2} \mathrm{H}_{2}=0.36, \mathrm{CH}_{4}=0.32$ and $\mathrm{C}_{2} \mathrm{H}_{4}=0.32$, the fault diagnostic is (High-energy electrical discharge), the same results as in the previous example.

TABLE II. MODIFICATION OF DUVAL TRIANGLE (DGA) DIAGNOSTIC GRAPH TO NUMERICAL METHOD

\begin{tabular}{|c|c|c|c|}
\hline $\mathrm{C} 2 \mathrm{H} 2 \%$ & CH4\% & $\mathrm{C} 2 \mathrm{H} 4 \%$ & Fault \\
\hline $0.00-0.02$ & $0.98-1.00$ & $0.00-0.02$ & $\begin{array}{l}\text { Partial discharge } \\
\text { (electrical fault) }\end{array}$ \\
\hline \multirow{2}{*}{$0.00-0.04$} & $0.46-0.80$ & $0.20-0.50$ & $\begin{array}{l}\text { Thermal fault } \\
300<\mathrm{t}<700^{\circ} \mathrm{C}\end{array}$ \\
\hline & $0.76-0.98$ & $0.02-0.20$ & $\begin{array}{c}\text { thermal fault } \\
\mathrm{t}<3000^{\circ} \mathrm{C}\end{array}$ \\
\hline $0.00-0.15$ & $0.00-0.50$ & $0.50-1.00$ & $\begin{array}{l}\text { Thermal fault } \\
t>700^{\circ} \mathrm{C}\end{array}$ \\
\hline $0.04-0.13$ & $0.47-0.96$ & $0.00-0.40$ & \multirow{3}{*}{$\begin{array}{l}\text { Mixtures of thermal } \\
\text { and electrical faults }\end{array}$} \\
\hline $0.13-0.29$ & $0.21-0.56$ & $0.40-0.50$ & \\
\hline $0.15-0.29$ & $0.00-0.35$ & $0.50-0.85$ & \\
\hline $0.13-0.29$ & $0.31-0.64$ & $0.23-0.40$ & \multirow{2}{*}{$\begin{array}{c}\text { Discharge of high } \\
\text { energy (electrical } \\
\text { fault) }\end{array}$} \\
\hline $0.29-0.77$ & $0.00-0.48$ & $0.23-0.71$ & \\
\hline
\end{tabular}

\section{CASE STUDY DISSOLVED GAS ANALYSIS}

The case study carried out from three different groups of transformers each group are identical in Abu-Sultan steam power plant. Fig. (2) Shows the schematic diagram configuration for transformers under testing. The first group of transformers are three single phase $192 \mathrm{MVA}, 15 / 220 \mathrm{KV}$, Off L.T.C. The Second group of transformers are three phase 16 MVA, $220 / 6.3 \mathrm{KV}$, ON.L.T.C, and the third group of transformers are three phase $16 \mathrm{MVA}, 15 / 6.3 / 6.3 \mathrm{KV}$, ON.L.T.C. The rating and (DGA) testing results for the abovementioned Power Transformer are shown in tables (III, IV).

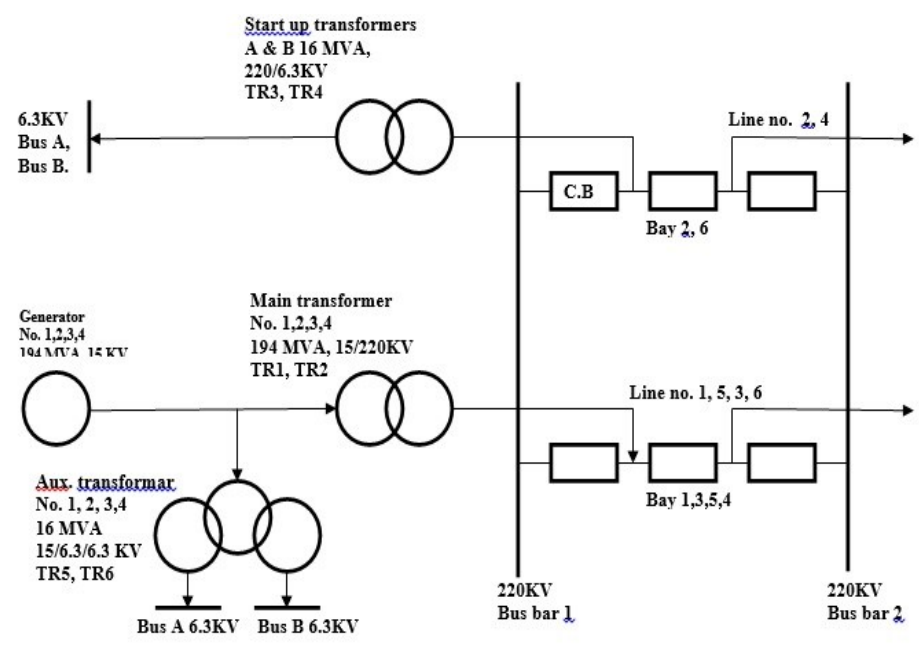

Fig. 2. Schematic Diagram for Transformers under Evaluation 
TABLE III.

RATING OF POWER TRANSFORMER UNDER TESTING

\begin{tabular}{|c|c|c|c|c|c|}
\hline 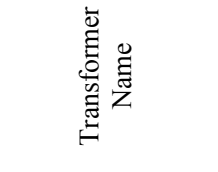 & 莺 & 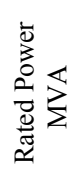 & 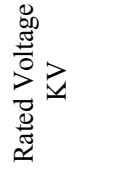 & 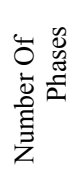 & 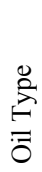 \\
\hline $\begin{array}{l}\text { Main transformer } \\
\text { Unit no. } 1\left(\mathrm{TR}_{1}\right)\end{array}$ & 19/3/1983 & \multirow{2}{*}{192} & \multirow{2}{*}{$15 / 220$} & \multirow[b]{2}{*}{ 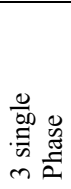 } & \multirow{6}{*}{ 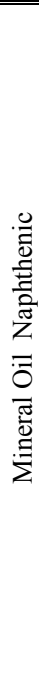 } \\
\hline $\begin{array}{l}\text { Main transformer } \\
\text { Unit no. } 2\left(\mathrm{TR}_{2}\right)\end{array}$ & $15 / 8 / 1983$ & & & & \\
\hline $\begin{array}{l}\text { Start Up } \\
\text { transformer A } \\
\left(\mathrm{TR}_{3}\right)\end{array}$ & $19 / 3 / 1983$ & \multirow[t]{2}{*}{16} & \multirow[t]{2}{*}{$220 / 6.3$} & \multirow[b]{2}{*}{ 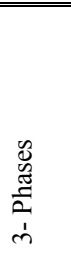 } & \\
\hline $\begin{array}{l}\text { Start Up } \\
\text { transformer B } \\
\left(\mathrm{TR}_{4}\right)\end{array}$ & $15 / 10 / 1984$ & & & & \\
\hline $\begin{array}{l}\text { Aux. transformer } \\
\text { unit no. } 1\left(\mathrm{TR}_{5}\right)\end{array}$ & $19 / 3 / 1983$ & 16 & $15 / 6.3 / 6.3$ & \multirow[b]{2}{*}{ 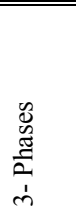 } & \\
\hline $\begin{array}{l}\text { Aux. transformer } \\
\text { Unit no. } 2 \quad\left(\mathrm{TR}_{6}\right)\end{array}$ & $15 / 8 / 1983$ & & & & \\
\hline
\end{tabular}

\section{DIAGNOSTIC METHOD USED BY MODIFICATION SYSTEM.}

The diagnostic methods for DGA are used by a numerical method, The Matlab program diagnoses output for the under testing transformers. Table (V) shows application of the faults diagnosed by various methods, which indicate that all transformers are thermal faults.

\section{RESULTS AND DISCUSSION}

Comparison of various methods as shown in the table (V), a thermal fault in oil within all transformers is diagnosed for all five methods. Where winding temperature do not exceed $95^{\circ} \mathrm{C}$ and oil temperature do not exceed $85^{\circ} \mathrm{C}$ for all transformers during normal operation. Moreover, the possible collapse of cooling system during operation in this case is too small and there is no increase in the viscosity of the oil, as it is clear in the results of chemical analysis of samples oil and no wax materials. However, there is an important factor is the increased over excitation due to reduction of generator speed when some of the generating units from the network goes out during normal operation or the frequency disturbances that occur when large loads are connected to the electrical network system.

Over-excitation or/and under frequency protection may be or may be not operate depends on the response of power system control. The under frequency relay operate at $47.5 \mathrm{~Hz}$ with time lag $0.5 \mathrm{sec}$ and over excitation relay operate at $\mathrm{V} / \mathrm{Hz}=1.1 \mathrm{pu}$ for $45 \mathrm{sec}$ time lag or $\mathrm{V} / \mathrm{Hz}=1.18 \mathrm{pu}$ for $2 \mathrm{sec}$ time lag at generators.
TABLE IV

(DGA) TESTING RESULTS

\begin{tabular}{|c|c|c|c|c|c|c|c|c|}
\hline 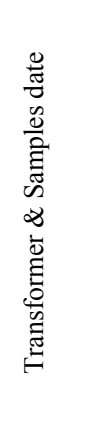 & & & 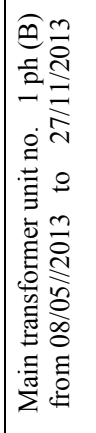 & 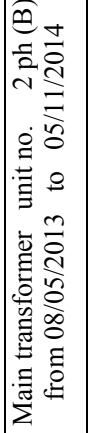 & 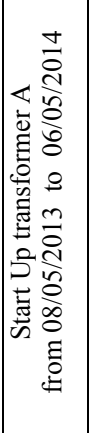 & 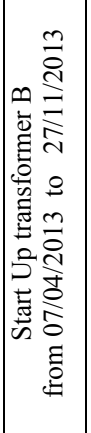 & 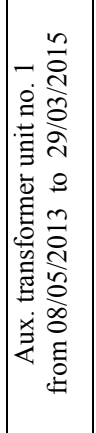 & 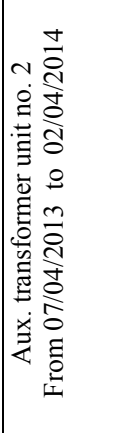 \\
\hline 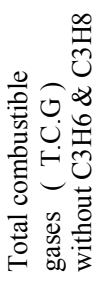 & & & $\begin{array}{l}274 \\
477\end{array}$ & $\begin{array}{l}164 \\
592\end{array}$ & $\begin{array}{l}98 \\
249\end{array}$ & $\begin{array}{l}219 \\
426\end{array}$ & $\begin{array}{l}246 \\
429\end{array}$ & $\begin{array}{l}193 \\
400\end{array}$ \\
\hline 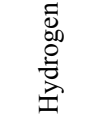 & \multirow{7}{*}{$\mid \begin{array}{l}0 \\
0 \\
0 \\
0 \\
0 \\
0 \\
0 \\
0: 0 \\
0 \\
0 \\
0 \\
0 \\
0 \\
0\end{array}$} & $\mathrm{H}_{2}$ & $\begin{array}{l}9 \\
7\end{array}$ & $\begin{array}{c}3 \\
16\end{array}$ & $\begin{array}{c}1 \\
19\end{array}$ & $\begin{array}{l}5 \\
6\end{array}$ & $\begin{array}{l}14 \\
28\end{array}$ & $\begin{array}{c}7 \\
35\end{array}$ \\
\hline \multirow{5}{*}{ 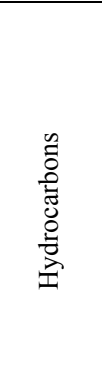 } & & $\mathrm{CH}_{4}$ & $\begin{array}{l}25 \\
48 \\
\end{array}$ & $\begin{array}{l}15 \\
37 \\
\end{array}$ & $\begin{array}{l}2 \\
4 \\
\end{array}$ & $\begin{array}{l}19 \\
61 \\
\end{array}$ & $\begin{array}{l}48 \\
49 \\
\end{array}$ & $\begin{array}{c}9 \\
12 \\
\end{array}$ \\
\hline & & $\mathrm{C}_{2} \mathrm{H}_{2}$ & $\begin{array}{l}0 \\
0 \\
\end{array}$ & $\begin{array}{l}0 \\
0\end{array}$ & $\begin{array}{l}0 \\
0 \\
\end{array}$ & $\begin{array}{l}0 \\
0 \\
\end{array}$ & $\begin{array}{l}0 \\
0 \\
\end{array}$ & $\begin{array}{l}0 \\
0 \\
\end{array}$ \\
\hline & & $\mathrm{C}_{2} \mathrm{H}_{4}$ & $\begin{array}{l}5 \\
2 \\
\end{array}$ & $\begin{array}{c}1 \\
12 \\
\end{array}$ & $\begin{array}{l}2 \\
8 \\
\end{array}$ & $\begin{array}{l}5 \\
6 \\
\end{array}$ & $\begin{array}{c}3 \\
10 \\
\end{array}$ & $\begin{array}{l}2 \\
3 \\
\end{array}$ \\
\hline & & $\mathrm{C}_{2} \mathrm{H}_{6}$ & $\begin{array}{l}12 \\
29 \\
\end{array}$ & $\begin{array}{l}10 \\
50 \\
\end{array}$ & $\begin{array}{l}1 \\
3 \\
\end{array}$ & $\begin{array}{c}57 \\
142 \\
\end{array}$ & $\begin{array}{l}28 \\
45 \\
\end{array}$ & $\begin{array}{l}2 \\
3 \\
\end{array}$ \\
\hline & & $\begin{array}{c}\mathrm{C}_{3} \mathrm{H}_{6} \\
\& \\
\mathrm{C}_{3} \mathrm{H}_{8}\end{array}$ & $\begin{array}{l}14 \\
26\end{array}$ & $\begin{array}{l}5 \\
-\end{array}$ & $\begin{array}{l}2 \\
3\end{array}$ & $\begin{array}{l}30 \\
81\end{array}$ & $\begin{array}{l}14 \\
-\end{array}$ & $\begin{array}{l}2 \\
3\end{array}$ \\
\hline \multirow{2}{*}{ 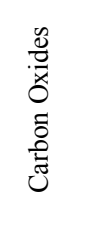 } & & $\mathrm{CO}$ & $\begin{array}{l}223 \\
392\end{array}$ & $\begin{array}{l}135 \\
477\end{array}$ & $\begin{array}{c}91 \\
215\end{array}$ & $\begin{array}{l}132 \\
212\end{array}$ & $\begin{array}{l}154 \\
297\end{array}$ & $\begin{array}{l}173 \\
348\end{array}$ \\
\hline & \multirow{3}{*}{ 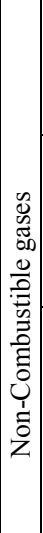 } & $\mathrm{CO}_{2}$ & $\begin{array}{l}2877 \\
6052\end{array}$ & $\begin{array}{c}775 \\
4854\end{array}$ & $\begin{array}{c}482 \\
1324\end{array}$ & $\begin{array}{c}848 \\
1772\end{array}$ & $\begin{array}{l}1632 \\
3787\end{array}$ & $\begin{array}{c}439 \\
2581\end{array}$ \\
\hline \multirow[b]{2}{*}{ 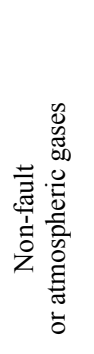 } & & $\mathrm{O}_{2}$ & $\begin{array}{l}2042 \\
2664\end{array}$ & $\begin{array}{l}1633 \\
3758\end{array}$ & $\begin{array}{l}3432 \\
5766\end{array}$ & \begin{tabular}{c|}
991 \\
1911
\end{tabular} & $\begin{array}{c}1420 \\
13615\end{array}$ & $\begin{array}{l}1118 \\
3300\end{array}$ \\
\hline & & $\mathrm{N}_{2}$ & $\begin{array}{l}31551 \\
38801\end{array}$ & $\begin{array}{l}45633 \\
90526\end{array}$ & $\begin{array}{l}39302 \\
56161\end{array}$ & \begin{tabular}{|l|}
74493 \\
88856
\end{tabular} \mid & $\begin{array}{l}82762 \\
137375\end{array}$ & $\begin{array}{c}\backslash \\
30606 \\
119152\end{array}$ \\
\hline
\end{tabular}


TABLE V.

APPLICATION OF THE FAULT DIAGNOSED BY VARIOUS METHODS

\begin{tabular}{|c|c|c|c|c|c|}
\hline 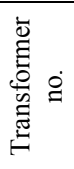 & $\begin{array}{c}\text { Duval's triangle } \\
\text { numerical modified } \\
\mathrm{P}(96 / 4)\end{array}$ & $\begin{array}{l}\text { Basic gas ratio } \\
\mathrm{P}(77 / 8)\end{array}$ & $\begin{array}{c}\text { Doernenburg ratio } \\
\mathrm{P}(71 / 3)\end{array}$ & $\begin{array}{l}\text { Rogers Ratio } \\
\text { P(62/5) }\end{array}$ & $\begin{array}{l}\text { Kay gas } \\
\mathrm{P}(42 / 58)\end{array}$ \\
\hline TR1 & $\begin{array}{c}\text { thermal fault } \\
\mathrm{t}<300^{\circ} \mathrm{C}\end{array}$ & $\begin{array}{c}\text { thermal fault } \\
t<300^{\circ} \mathrm{C}\end{array}$ & $\begin{array}{c}\text { thermal } \\
\text { decomposition }\end{array}$ & $\begin{array}{c}\text { slight overheating } \\
\mathrm{t}<150^{\circ} \mathrm{C}\end{array}$ & pyrolysis in cellulose \\
\hline TR2 & $\begin{array}{c}\text { Thermal fault } \\
300<\mathrm{t}<700^{\circ} \mathrm{C}\end{array}$ & $\begin{array}{c}\text { thermal fault } \\
\mathrm{t}<300^{\circ} \mathrm{C}\end{array}$ & $\begin{array}{c}\text { thermal } \\
\text { decomposition }\end{array}$ & $\begin{array}{c}\text { slight overheating } \\
150-200^{\circ} \mathrm{C}\end{array}$ & pyrolysis in cellulose \\
\hline TR3 & $\begin{array}{c}\text { Thermal fault } \\
\mathrm{t}>700{ }^{\circ} \mathrm{C} \\
\end{array}$ & $\begin{array}{l}\text { thermal fault of low } \\
\text { temperature } \mathrm{t}<150^{\circ} \mathrm{C}\end{array}$ & Cannot be applicable & $\begin{array}{c}\text { general conductor } \\
\text { overheating }\end{array}$ & pyrolysis in cellulose \\
\hline TR4 & $\begin{array}{l}\text { thermal fault } \\
\mathrm{t}<300^{\circ} \mathrm{C}\end{array}$ & $\begin{array}{c}\text { thermal fault } \\
\mathrm{t}<300^{\circ} \mathrm{C}\end{array}$ & $\begin{array}{c}\text { thermal } \\
\text { decomposition }\end{array}$ & $\begin{array}{c}\text { slight overheating } \\
150-200^{\circ} \mathrm{C}\end{array}$ & pyrolysis in cellulose \\
\hline TR5 & $\begin{array}{c}\text { Thermal fault } \\
t>700{ }^{\circ} \mathrm{C}\end{array}$ & $\begin{array}{c}\text { thermal fault } \\
\mathrm{t}<300^{\circ} \mathrm{C}\end{array}$ & $\begin{array}{c}\text { thermal } \\
\text { decomposition }\end{array}$ & Cannot be applicable & pyrolysis in cellulose \\
\hline
\end{tabular}

If frequency decreases and the voltage is constant, the transformer core is heated. Fig. (3) Shown voltage, current and frequency of generating unit transformer number one at Abusultan steam power plant from 17/5/2015 to18/5/2015, which indicate that frequency, reduced to $49.2 \mathrm{~Hz}$ at voltage 14.85 . KV.

The rated generator voltage and frequency is $15 \mathrm{KV}$ and $50 \mathrm{~Hz}$ respectively. So generator is over excitation $=1.0061 \mathrm{Pu}$. At unit, start up the voltage may be built to $15 \mathrm{KV}$ at generator frequency $48 \mathrm{~Hz}$ then $1.042 \mathrm{Pu}$ over-excitations. Disturbance in frequency is repeated from $18 / 5 / 2015$ to $20 / 5 / 2015$ in power system as shown in Fig. (4) and affect all network transformers in this moment and there is an instantaneous decrease in power system frequency to $45.36 \mathrm{~Hz}$ without operate under frequency or/and over-excitation relays because disturbance duration less than $0.5 \mathrm{sec}$ as shown in Fig. (5).

Transformers require an internal magnetic field to operate. The core of a transformer is designed to provide the magnetic flux Necessary for rated load.

An over-excitation condition occurs when this equipment is operated such that flux levels exceed design values. The voltage output of a transformer is a function of the rate of change of the flux and the number of turns in the output winding. $e=N d \varphi / d t$ during normal power system operation.

The voltage is sinusoidal and the rate of change is determined by the frequency, which is in turn determined by generator speed [14].

The equation shows core flux to be directly proportional to voltage and inversely proportional to frequency $\varphi \alpha \mathrm{V} / \mathrm{f}$. The actual magnitude of flux in transformer core is can be quantified in terms of per unit volts / Hertz.

A generator or transformer operating at no load with rated voltage and frequency would have one per unit excitation. The same equipment operating at rated voltage and $95 \%$ frequency would have $1.0 / 0.95=1.05 \mathrm{Pu}$ flux or $1.05 \mathrm{Pu}$ excitation.

Over-excitation will result from high voltage at rated frequency and from rated voltage with low frequency.

Because over excitation is a function of voltage and frequency, it can occur without notice. Transformers and generators can be subject to repeated over excitation by inappropriate operating.
The practices or operator error without a disruption to operations. The resulting thermal faults lead to oil decomposing to generate fault gases $\mathrm{H}_{2}, \mathrm{CH}_{4}$ at temperature $120^{\circ} \mathrm{C}, \mathrm{C}_{2} \mathrm{H}_{6}$ at temperature $150^{\circ} \mathrm{C}, \mathrm{C}_{2} \mathrm{H}_{4}$ at temperature $300^{\circ} \mathrm{C}$, and $\mathrm{C}_{2} \mathrm{H}_{2}$ at temperature $700^{\circ} \mathrm{C}$.

In addition, degradation of insulating material is cumulative. A transformer or generator that survives a serious over excitation event or many small events may fail because of a moderate event during normal service as all transformers under study.

In addition, if voltage increased, at rated frequency, the exciting current increases, as shown in Fig. (6). So $\operatorname{Tr}_{1}$ through $\operatorname{Tr}_{6}$ are effected by over excitation due to network normal operation but $\operatorname{Tr}_{1}, \operatorname{Tr}_{2}, \operatorname{Tr}_{5}, \operatorname{Tr}_{6}$ are effected by Over excitation damage usually occurs during periods of off-frequency operation such as start up or shut down for unit transformer as shown in Fig.(2) and table (VI). 


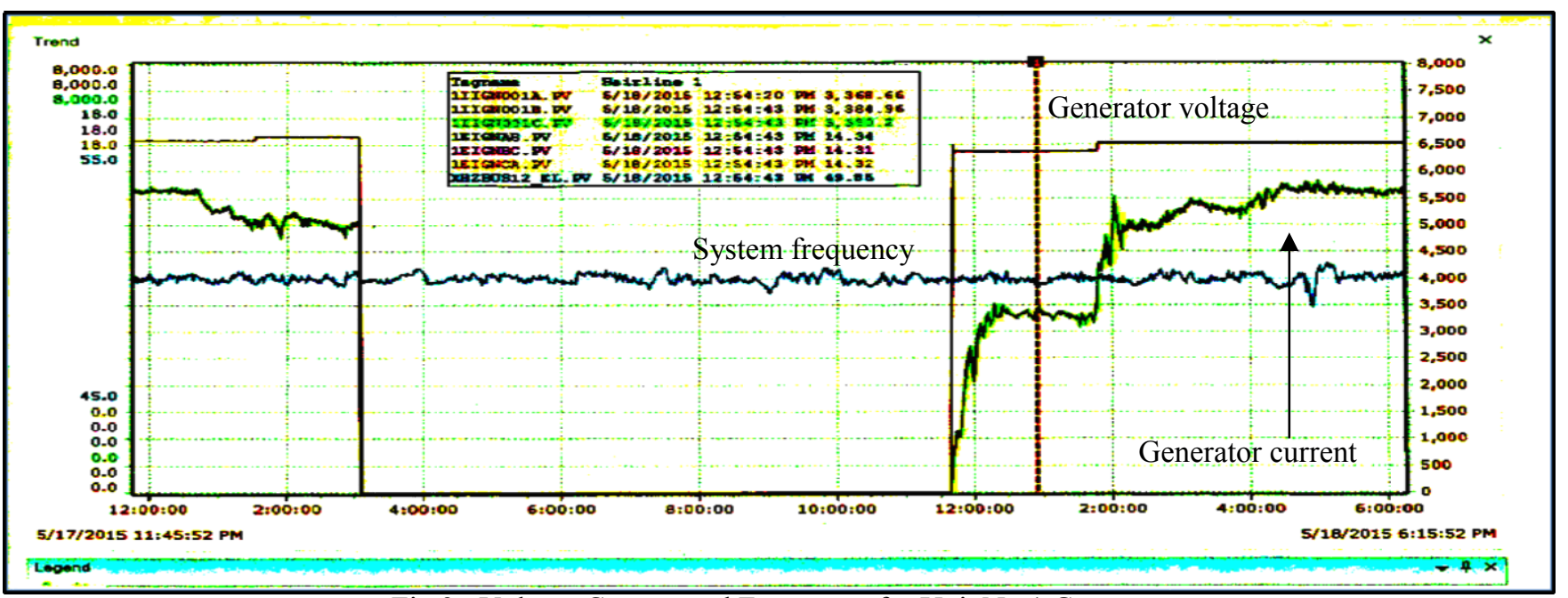

Fig 3. Voltage Current and Frequency for Unit No.1 Generator

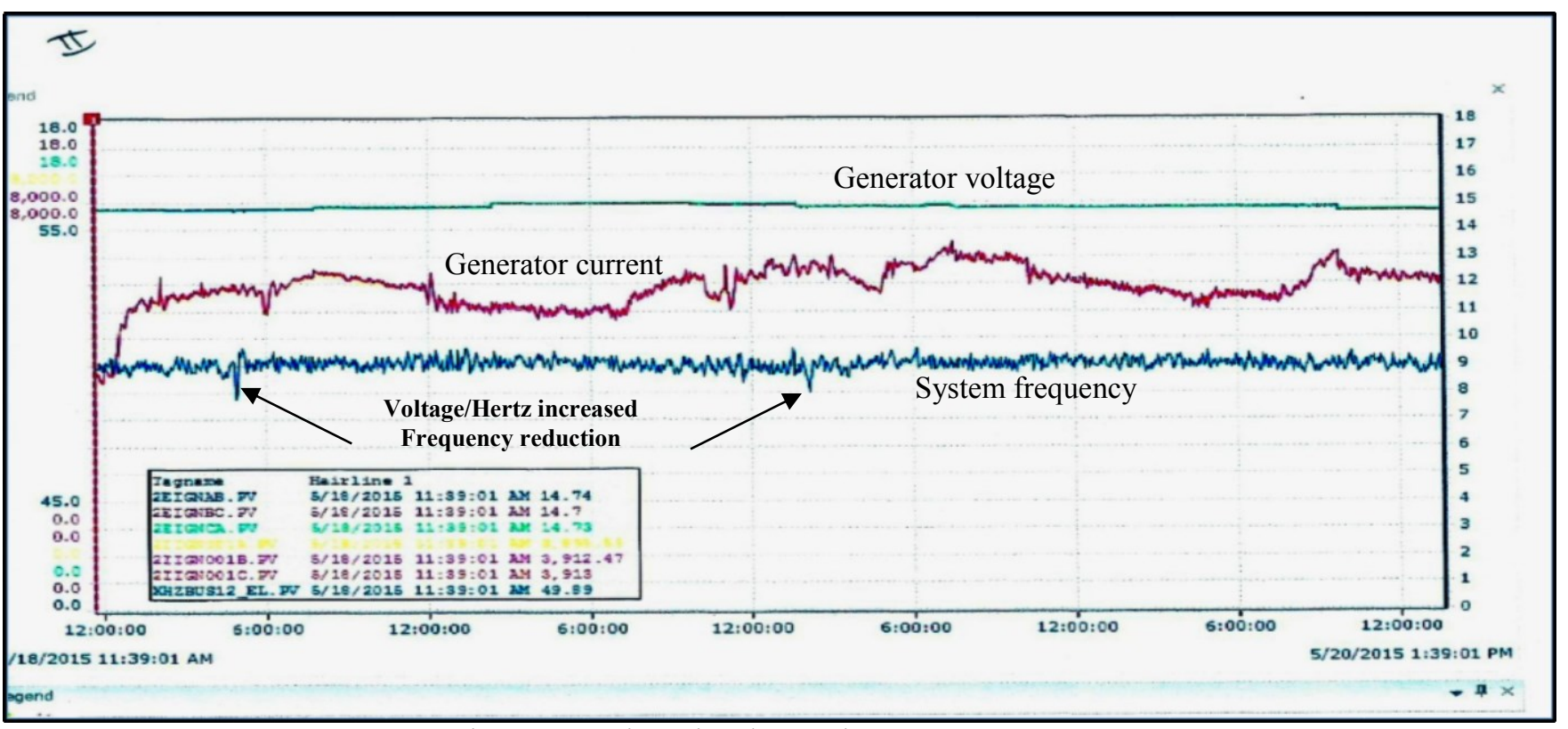

Fig 4. Repeating Disturbances in Power System Frequency

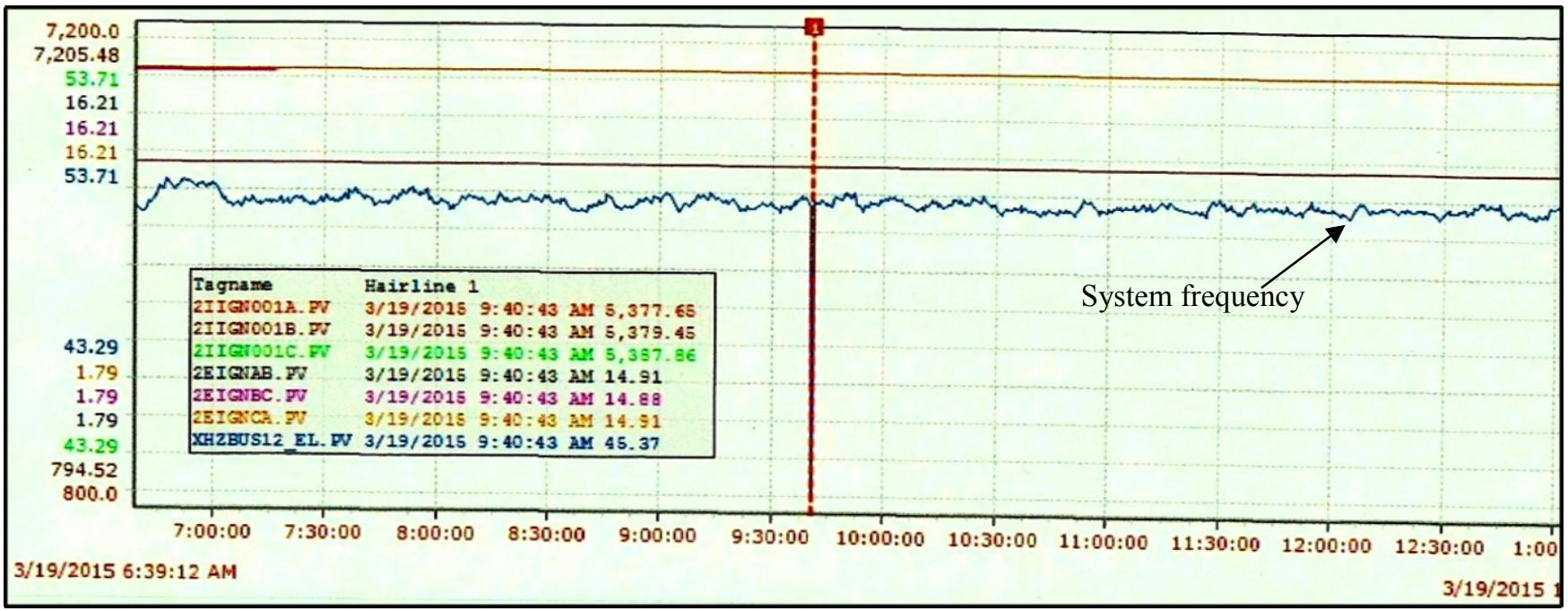

Fig 5. Instantaneous Decrease in Power System Frequency 


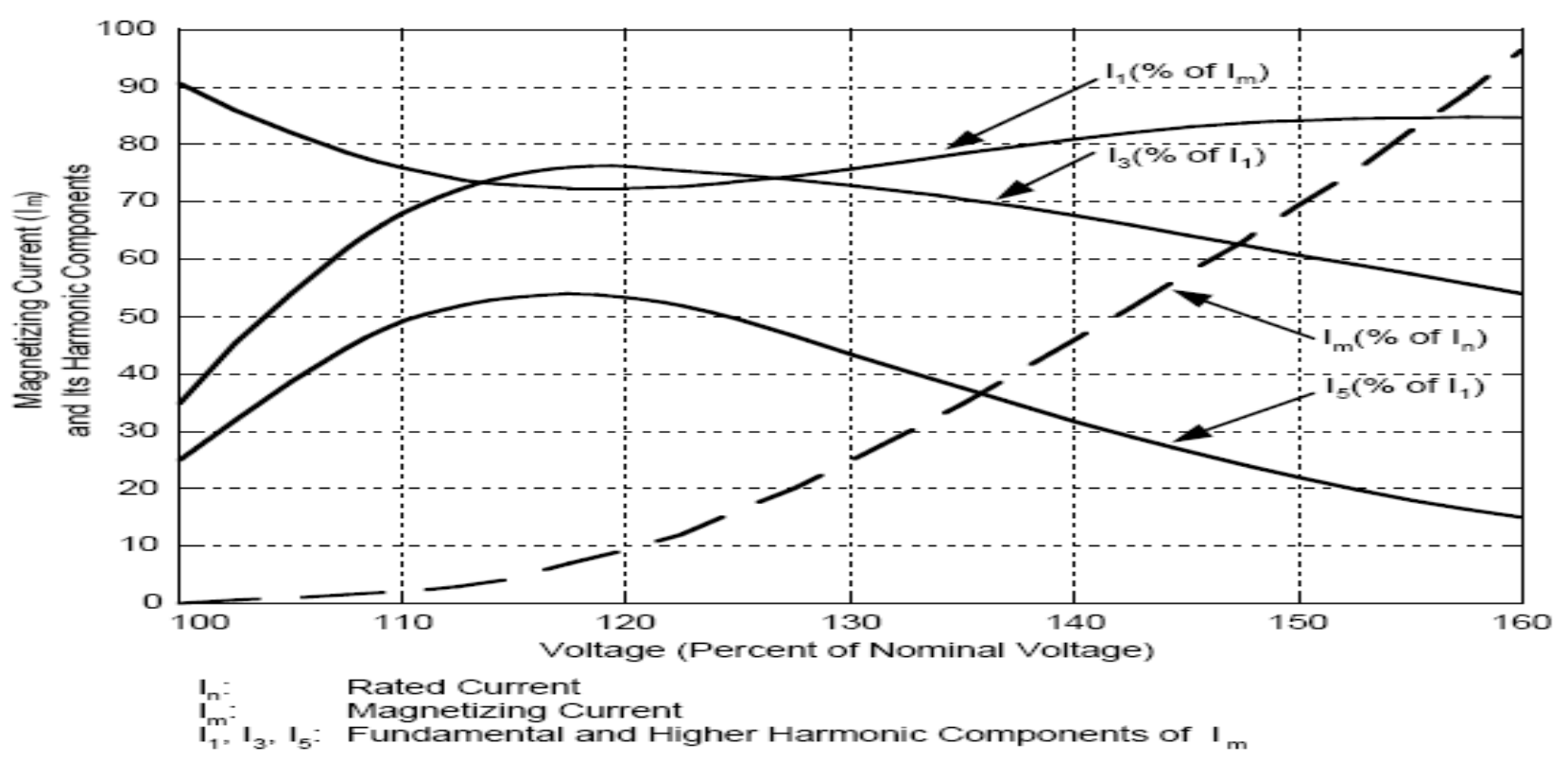

Fig 6. Voltage Increased, at Rated Frequency Exciting Current Increase

TABLE VI

CAUSES OF THERMAL FAULTS, NORMAL AND ACCELERATED AGING

\begin{tabular}{|c|c|c|c|c|c|c|c|c|c|}
\hline & & & & $\operatorname{Tr} 1$ & $\operatorname{Tr} 2$ & $\operatorname{Tr} 3$ & $\operatorname{Tr} 4$ & $\operatorname{Tr} 5$ & $\operatorname{Tr} 6$ \\
\hline \multirow{8}{*}{ 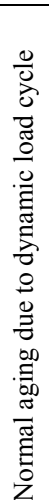 } & \multirow{4}{*}{ 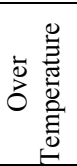 } & \multicolumn{2}{|c|}{ Fault currents } & & & & & & \\
\hline & & \multicolumn{2}{|c|}{ Overload \&Unbalanced load } & & & & & & \\
\hline & & \multicolumn{2}{|c|}{ Cooling system failure } & & & & & & \\
\hline & & \multicolumn{2}{|c|}{ Increased Oil viscosity } & & & & & & \\
\hline & \multirow{4}{*}{ 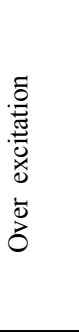 } & Unit startup & $\begin{array}{l}\text { maintain the set point voltage at } \\
\text { low frequency }\end{array}$ & $\mathrm{X}$ & $\mathrm{X}$ & & & $\mathrm{X}$ & $\mathrm{X}$ \\
\hline & & Unit shutdown & $\begin{array}{l}\text { field breaker fails to open when } \\
\text { the generator trips }\end{array}$ & $\mathrm{X}$ & $\mathrm{X}$ & & & $\mathrm{X}$ & $\mathrm{X}$ \\
\hline & & Over Voltage At rated frequency & $\begin{array}{l}\text { The charging current for a high- } \\
\text { voltage transmission line. }\end{array}$ & $\mathrm{X}$ & $\mathrm{X}$ & $\mathrm{X}$ & $\mathrm{X}$ & $\mathrm{X}$ & $\mathrm{X}$ \\
\hline & & $\begin{array}{l}\text { Power system } \\
\text { disturbance }\end{array}$ & $\begin{array}{l}\text { Loss of some units } \\
\text { During operation or suddenly } \\
\text { heavy load }\end{array}$ & $\mathrm{X}$ & $\mathrm{X}$ & $\mathrm{X}$ & $\mathrm{X}$ & $\mathrm{X}$ & $\mathrm{X}$ \\
\hline \multirow{3}{*}{ 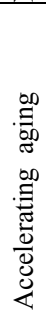 } & \multirow{3}{*}{ 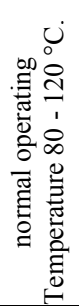 } & Moisture & \multirow{3}{*}{$\begin{array}{l}\text { Oxidation of the insulation and } \\
\text { oils forms acids, Acid attacks } \\
\text { cellulose and accelerates } \\
\text { insulation degradation, with } \\
\text { moisture (PD) Electrical stress } \\
\text { can occur and more insulation } \\
\text { degradation }\end{array}$} & & & & & & $\mathrm{X}$ \\
\hline & & Oxygen & & & & & & & $\mathrm{X}$ \\
\hline & & Acidity & & & & & & & $\mathrm{X}$ \\
\hline
\end{tabular}

\section{CONCLUSION.}

Modification of Duval triangle DGA diagnostic graph to numerical method is easy to use for diagnoses and a Matlab program. Transformer thermal faults during dynamic load cycle due to temperature increase from over load, cooling system failure or trouble, fault currents and /or over excitation condition.

Over excitation, damage usually occurs during periods of off-frequency operation such as start up or shut down for unit transformer. In addition, the fault gases can be generated due to oil decomposing effected by transformer over excitation.
Transformers and generators can be subject to repeated over excitation by inappropriate operating practices or operator error without a disruption to operations. It's can be concluded also, the resulting thermal faults lead to oil decomposing to generate fault gases $\mathrm{H} 2, \mathrm{CH} 4$ at temperature $120^{\circ} \mathrm{C}, \mathrm{C} 2 \mathrm{H} 6$ at temperature $150^{\circ} \mathrm{C}, \mathrm{C} 2 \mathrm{H} 4$ at temperature $300^{\circ} \mathrm{C}$, and $\mathrm{C} 2 \mathrm{H} 2$ at temperature $700^{\circ} \mathrm{C}$.

The gas type and gas quantity depends on the intensity and duration of Over-excitation. Transformer diagnostic thereby results depends on the events inside evaluation interval or before evaluation time. 


\section{REFERENCES}

[1] T. K. Saha, "Review of modern diagnostic techniques for assessing insulation condition in aged transformers", IEEE Transactions on Dielectrics and Electrical Insulation, Vol. 10, pp. 903-917, 2003.

[2] A. Abu-Siada and S. Islam, "A new approach to identify power transformer criticality and asset management decision based on dissolved gas-in-oil analysis", IEEE Transactions on Dielectrics and Electrical Insulation, Vol. 19, pp. 1007-1012, 2012.

[3] "IEEE guide for the interpretation of gases generated in oilimmersed transformers", IEEE Standard C57.104-2008, 2009.

[4] M. J. Heathcote, the J \& P Transformer Book, Twelfth Edition, Reed Educational and Professional Publishing Ltd, 1998.

[5] S. M. Islam, T. Wu and G. Ledwich, "A novel fuzzy logic approach to transformer fault diagnosis", IEEE Transactions on Dielectrics and Electrical Insulation, Vol. 7, pp. 177-186, 2000.

[6] M. A. Izzularab, G. E. M. Aly and D. A. Mansour, "On-line diagnosis of incipient faults and cellulose degradation based on artificial intelligence methods", IEEE International Conference on Solid Dielectrics (ICSD), pp. 767-770, 2004.

[7] Md Umar Farooque, Shufali Awani,Shakeb akan "Artificial neural network (ANN) based implementation of Duval pentagon"2015 International Conference on condition assesment techniques in electrical systems (CATCON) pp 46-50, 2015.

[8] Diaa-ELdin A.Monsour "-Development of a new graphical technique for dissolved gas analysis in power transformers based on the five combustible gases"IEEE Transactions on Dielectrics and Electrical Insulation, Vol. 22, pp. 2507 - 2512, 2015.

[9] Alamuru Vani and Pessapaty Sree Rama Chandra Murthy" Hybrid diagnosing techniques for analyzing dissolved gases in power transformers " ISSN 2006 - 9790, pp 33-34, 2015.

[10] M. Duval, "A review of faults detectable by gas-in-oil analysis in transformers", IEEE Electrical Insulation Magazine, Vol. 18, pp. 8-17, 2002.

[11] Nitin K. Dhote1 and Jagdish B. Helonde" Fuzzy Algorithm for Power Transformer Diagnostics" Academic Editor: M. Onder Efe, pp 1-2, 2013.

[12] Stefan Tenbohlen, Sebastian Coenen , Mohammad Djamali " Andreas Müller Diagnostic Measurements for Power Transformers" Academic Editor: Issouf Fofana, Energies, pp 2, 2016.

[13] Sherif S.M.Ghoneim , Ibrahim B.M.Taha , Nagy I.Elkalashy "Integrated ANN-Based Proactive Fault Diagnostic Scheme for Power Transformers Using Dissolved Gas Analysis" IEEE Transactions on Dielectrics and Electrical Insulation, Vol.23, No 3 , pp1838-1845, 2016

[14] L.G Hewitson "Protective Relaying for Power Generation Systems" Book Taylor \& Francis Group, Publishing Ltd 2006.

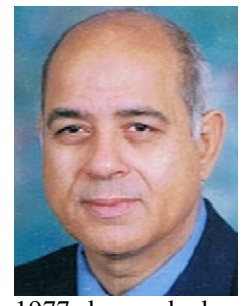

Sobhy Serry Dessouky was born in Dakahlie of Egypt in 1946. He received the B.Sc. degree (1970) and M.Sc. (1977) in electrical engineering from Suez Canal University in Helwan University respectively. Dr. Dessouky received the Ph. D. degree from TU, Dresden, German in 1982. From Oct. 1970 to 1975 , he was Joined Faculty of Engineering, Suez Canal University, as Demonstrator. He worked as Demonstrator from 19751977 in Faculty of Engineering, Helwan University. In 1977, he worked as lecturer assistant in Electrical Engineering Department, Faculty of Engineering, Suez Canal University. From 1983 to 1987, he worked as Assistant Professor (Lecturer), in Electrical Engineering Department, faculty of Engineering, Suez Canal University, Port Said Campus. In 1987, he promoted as Associate Professor in the same Department. In 1991, Dr. Dessouky became a full Professor of Electrical power and H.V Engineering. He was a member in IEEE from 1996. In parallel, he worked as a department chair, Vice Dean for Community Affairs and Environment, and Director of Engineering Research Center for Developing and Technological Planning in Suez Canal University.

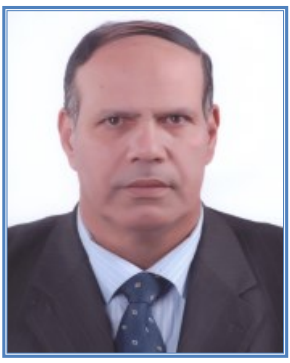

Ahmed E.Kalas received the B.Sc. degree in electrical engineering from the Suez Canal University with honor first rank in EGYPT 1982, M.Sc. degree (Power electronic and electrical Drives), from the Suez canal university, EGYPT 1987, ph. D. degree (Power electronic and electrical Drives) from Gdansk university, POLAND 1994 From 1994 up to 2010 he worked as a lecture in electrical engineering at Suez canal university, from 2010 up to now he worked as a lecture in electrical engineering at port said university research contributions, as well as his on-going efforts/investigations in the area of AC drives and power electronics, can be classified into the following topics:

Control of electric machines; Vector control, nonlinear control, adaptive control, model predictive control, double feed induction motors, DTC -Power electronic converters, two-level and multilevel, matrix converter, ZS-Artificial Intelligence in machines and power electronics control, Fuzzy logic, neural networks -Renewable energy conversion for PV and wind systems, maximum power point tracking -Fault detection Diagnosis in electrical machines and drives.

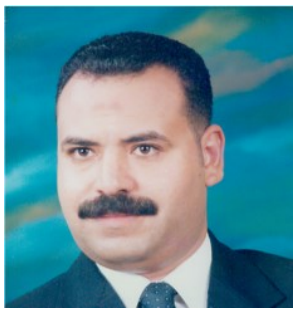

R.A.Abd El-Aal was born in Egypt, 1971. He received the B.Sc. degree (1996) and M.Sc. (2002) in electrical engineering from Suez Canal University. He received the Ph. D. degree in H.V Engineering from Port Said University in 2008. $\mathrm{He}$ works as lecture in electrical engineering Dept., Port Said University, Egypt. His research interests are H.V Engineering and power system protection.

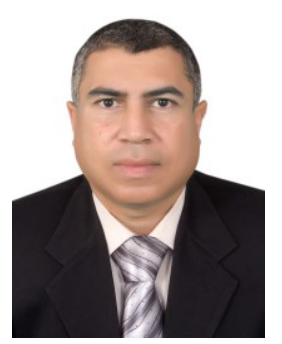

Abdel Moneim M. Hassan. was born in Ismailia of Egypt in 1963. He received the B.Sc. degree (1986) in electrical engineering from Helwan University. He works as General Manager in Abu Sultan steam power plant 4*150 MW, from 1988 to 1998 , He worked in operation department as operation engineer in Abu Sultan power plant, from 1998 to 2014, He worked as electrical maintenance, measuring and protection engineer in the same plant. 